\title{
Production of Cocoa Butter Substitute from Extra Virgin Olive Oil Rich in Omega-9 and Polyphenols
}

\author{
Shaker M. Arafat ${ }^{1}$, Amany M. Basuny², Dalia M. Hikal ${ }^{3}$ \\ ${ }^{1}$ Oils \& Fats Research Department, Food Technology Research Institute, Agriculture Research Center, Giza, Egypt \\ ${ }^{2}$ Biochemistry Department, Faculty of Agriculture, Beni-Suef University, Beni Suef, Egypt \\ ${ }^{3}$ Nutrition and Food Science, Home Economics Department, Faculty of Specific Education, Mansoura University, Mansoura, Egypt \\ Email:dr.daliahikal@mans.edu.eg
}

How to cite this paper: Arafat, S.M., Basuny, A.M. and Hikal, D.M. (2021) Production of Cocoa Butter Substitute from Extra Virgin Olive Oil Rich in Omega-9 and Polyphenols. Food and Nutrition Sciences, 12, 614-626.

https://doi.org/10.4236/fns.2021.126046

Received: May 29, 2021

Accepted: June 26, 2021

Published: June 29, 2021

Copyright $\odot 2021$ by author(s) and Scientific Research Publishing Inc. This work is licensed under the Creative Commons Attribution International License (CC BY 4.0).

http://creativecommons.org/licenses/by/4.0/

\begin{abstract}
The objective of this study was to produce healthy cocoa butter substitutes from extra virgin olive oil rich in omega-9 and polyphenols by blending process with palm oil avoiding hydrogenation and esterification processes. Oil blends, formulated by binary blends of palm oil and extra virgin olive oil at different ratios (90:10, 80:20 and 70:30) compared with commercial cocoa butter. The physicochemical properties (refractive index, melting and slip point, color index, acidity, peroxide value, iodine number and induction period by Rancimat method) have been determined for palm and olive oils and the produced cocoa butter substitute. Also, fatty acid composition was identified by gas liquid chromatography and solid fat content of the produced cocoa butter substitute was measured by Nuclear Magnetic Resonance (NMR) and total polyphenols of oils and produced cocoa butter substitute were determined. The results indicated that all the values of melting and slip point were about the human body temperature $\left(37^{\circ} \mathrm{C}\right)$, also results show a high content of cocoa butter produced from oleic acid, as well as phenolic compounds, and this leads to an increase in oxidative stability.
\end{abstract}

\section{Keywords}

Cocoa Butter, Extra Virgin Olive Oil, $\omega$-9-Fatty Acids, Polyphenols, Blending Process

\section{Introduction}

The soft, yellow and edible fat derived from a cocoa bean is cacao butter often called Theobroma oil. It is used for the processing of chocolate and certain 
points, toiletries and medications [1]. The taste and fragrance of cacao butter: Cocoa butter, because of its distinctive physical properties, are the most costly fat and the main component in chocolate candy goods. Cocoa butter has a small range of melting points $\left(27^{\circ} \mathrm{C}-33^{\circ} \mathrm{C}\right)$, is strong, brittle and melts with a maximum feeling of cooling in the mouth [2]. Cocoa butter produces a high share of saturated and monounsaturated oleic acid, normally found in any triglyceride. POS, SUS, POP, with $\mathrm{P}=$ palmtic, $\mathrm{O}=$ oleic, and $\mathrm{S}=$ residue of stearic [3] are the most prevalent triglycerides. Cocoa butter is cheaper and costlier than other vegetable fats and oil owing to its unique chemical and physical properties. According to the 2019 Global Market Forecast, the demand for cocoa butter will rise at a yearly growth rate of 7.3\% in five years and is projected to hit USD 16.32 billion [4]. In view of the increase in consumption of chocolate products, poor profits and low salaries at the plant, market analysts have forecasted that the scarcity of cocoa butter would remain a persistent risk to food suppliers [5]. These researchers have therefore urged food processing companies to look to the development of cocoa butter substitutes, an alternative from plant sources, to substitute cocoa butter, partly or entirely, for economic and technical reasons in food products [6]. Cocoa butter includes only amounts of caffeine and theobromine, in contrast to non-fat cocoa solids. Butter of cocoa is getting more and more competitive. Replacements were planned to be used as replacements. The food can be labelled chocolate in the United States with $100 \%$ cocoa butter. The EU specifies that the overall fat content of alternative fats should not reach $5 \%$. Substitutes for these include: almond, banana, fatty mango kernel and mango kern fat mixture and banana oils; oils such as rapeseeds, cottons and illip oils, and shea butter. Cocoa butter is an important ingredient in nearly all forms of chocolates (white, dark and milk chocolate). Cocoa butter is now being taken through this program [7] [8]. Cocoa butter is widely used by pharmaceutical firms for physical products. As a nontoxic solid at room temperature that melts at body temperature, it is considered an ideal base for medicinal suppositories. A clear example of value-added goods by interesterification is the usage of inexpensive exchange oils in cocoa butter. This can be done with sn-1,3 specific lipases which catalase the integration in the sn-1,3 positions of the source oil containing oleic acid in the sn-2 location of palmic acid (PA) and stearic acid (SA) until similar composition of the TAG in cocoa butter is achieved [9].

$100 \%$ olive juice is extra-virgin olive oil. The oils are produced by sufficient maturation of the olives and by the mechanical pressing of the oil. The best quality olive oil is extra virgin [10]. The olives have an outstanding appearance and smell, which is free from defects and selected at full maturity and offer a festival for the senses [11]. Extra-virgin olive oil contains natural antioxidants like olive oil polyphenols and vitamin E, which have proven capable of cholesterol lowering, a preventive factor for heart disease, as well as a source of monounsaturated fatty acids [12].

Blending oils is a practical approach to boost the consistency of thermal oils. 
This will help to satisfy the taste and dietary demands of the customer in foodstuffs [13]. In pastry products, cocoa butter has the key role to play in supplying the necessary physical properties such as freezing, microstructure and strong fat. The fat used to substitute cocoa butter could also not drastically affect the quality of cocoa butter. The goal of this analysis was to eliminate cocoa butter by combining vegetable oils (palm oil and extra virgin olive oil) to different degrees.

\section{Materials \& Methods}

\subsection{Source of Materials}

A cocoa butter substitute delivered from local market used in this study as a reference guide was exported by Overseas Company (El-Shamadan) for Food Industries, Alexandria, Egypt. Refined, Bleached and Deodorized (RBD) palm oil was obtained from the Extracted Oils and Derivatives Company (Arma Company), $10^{\text {th }}$ of Ramadan City, Egypt. Olive oil was extracted from the olive sample (Coratina) cultivated in farm of Horticulture Research Centre as follows: Crushing of olive fruits were performed using experimental crusher mill, then (Carver) press, the pressure used was $12.000 \mathrm{lb} / \mathrm{in}^{2}$, which was reached gradually. The resulting liquid phase was put in a separator funnel and allowed to stele for $50 \mathrm{~min}$. The upper oil layer was decanted threw dried over anhydrous sodium sulphate then filtered through a Whatman No.1 filter paper and kept in brown glass bottle $(120 \mathrm{~mL})$. All chemical and reagents of the analytical methods used in present study were analytical grade purchased from sigma-Aldrich Company for chemicals, USA and El-Gomhoriya Trading Chemicals and Drugs Company, Egypt. Pure standards of fatty acids methyl esters used in this study were obtained from Koch light Laboratories, Ltd., England.

\subsection{Preparation of Cocoa Butter Substitute}

Cocoa butter substitutes have been produces by blending process of palm oil and olive oil. The melting point and slip point behavior theoretically calculated then modified the blend ratios. All tested blends components were individually melted at $70^{\circ} \mathrm{C} \pm 2{ }^{\circ} \mathrm{C}$ in water bath prior to blending process. A cooling unit (Refrigerated Temperature Bath Model TC-500 serial 194042101, USA) fixed on $5^{\circ} \mathrm{C} \pm 1^{\circ} \mathrm{C}$ was used as well as homogenizing stirrer (Fisher Scientific Mix Model 143 , USA) was, fixed on $300 \mathrm{rpm}$. This process taken within $1 \mathrm{~min}$ to $3 \mathrm{~min}$ to get the desire texture of cocoa butter alternatives, the times were measured by calibrated stopwatch to produce $100 \mathrm{~g}$ of blends samples [14]. The liquefied tested samples were mixed in proportions ranging as follows: 1) palm oil 80:20 olive oil, 2) Palm oil 70:30 olive oil and 3) Palm oil 60:40 olive oil.

\subsection{Physicochemical Properties of Oils and Cocoa Butter Substitute}

Refractive index, melting and slip points and color index, acidity, peroxide value, 
conjugated diene at $232 \mathrm{~nm}$, conjugated triene at $268 \mathrm{~nm}$, iodine number and unsaponifiable matter were determined according to the method described by A.O.C.S. 2012 [15].

\subsection{Oxidative Stability of Oils and Cocoa Butter Substitute}

Tests of the infusion times were conducted on the checked samples to easily demonstrate the characteristics of oxidative rancidity tolerance as well as the samples' shelf life. According to the protocol outlined in [16], an automatic Rancimat analysis was carried out of the collected samples (Metrohm Ud. CH-9100 Herisau, Switzerland, model 679) and the wet segment of 6 reaction vessels in the oxidative stability index (2008).

\subsection{Identification of Fatty Acids of Oils and Cocoa Butter Substitute}

Fatty acid methyl esters were prepared using quick methods in accordance with ISO 12966-2 (2011) from total lipids. A column DB-23 (60 m to $0.32 \mathrm{~mm}$ daily) (DB-25 $\mu \mathrm{m}$ ) was supplied with fatty acid methyl ester (HP 6890 sequence GC). Carrier gas was $\mathrm{N}_{2}$ with $2.2 \mathrm{~mL} / \mathrm{min}$ flow rate, dividing ratio of 1:50. The flammable Ionization Detector (FID) had a temperature between $250^{\circ} \mathrm{C}$ and $300^{\circ} \mathrm{C}$. The temperature was set to: $150^{\circ} \mathrm{C}$ to $210^{\circ} \mathrm{C}$ at $5^{\circ} \mathrm{C}$ per minute, and held for 25 minutes at $210^{\circ} \mathrm{C}$. The overall retention periods were contrasted with normal methyl esters. Peaks were established.

\subsection{Solid fat Content of Oils and Cocoa Butter Substitute}

The solid fat content (SFC) of the tested samples was determined by Nuclear Magnetic Resonance (NMR) using a Bruker Minispec Analyzer (Model NO.120, Rheirstetten, Germany) according to the [17]. The tested samples were measured at $10^{\circ} \mathrm{C}, 20^{\circ} \mathrm{C}, 25^{\circ} \mathrm{C}, 30^{\circ} \mathrm{C}, 35^{\circ} \mathrm{C}, 40^{\circ} \mathrm{C}, 45^{\circ} \mathrm{C}$ and $50^{\circ} \mathrm{C}$.

\subsection{Determination of Total Polyphenols}

The levels of total polyphenols of palm and olive oils and cocoa butter substitute samples were determined according to the method of [18]. Caffeic acid was served as a standard compound for the preparation of the calibration curve.

\subsection{Data Analysis}

Statistical analysis was performed by using a one-way analysis of variance (ANOVA), followed by Duncan's test according to the procedure of using SPSS version 17 . The obtained results are expressed as mean \pm Standard Deviation (SD).

\section{Results and Discussion}

\subsection{Physicochemical Properties of Palm and Olive Oils}

The aim of this paper was to produce cocoa butter substitute from some vegetable oils by blending process avoiding hydrogenation or esterification processes. 
The vegetable oils used in this study were palm oil and olive oil at various concentrations. Figure 1 showed the physicochemical properties of palm and olive oils used in the production of cocoa butter. From the results obtained in Figure 1 (a) could be observed that refractive index was determined at $40 \mathrm{C} \pm 1$ for palm and olive oils. The refractive index values were 1.4556 and 1.4702 for palm and olive oils that showed clearly the different degree of unsaturation. The melting and slip point of the oils used in producing cocoa butter are shown in Figure 1(b) \& Figure 1(c) where palm oil represented to have the highest values of melting and slip point being $\left(40.00^{\circ} \mathrm{C}-42.00^{\circ} \mathrm{C}\right.$ ); followed by olive oil (from $-5.00^{\circ} \mathrm{C}$ to $-6.00^{\circ} \mathrm{C}$ ), respectively. The data in Figure $1(\mathrm{~d})$ illustrated that palm and olive oils nearly had the same values of yellow index which scaled 35.00. Also, the red color was scaled for palm olive oils were 2.10 and 2.30 , respectively. May be the color of olive oil was based upon pigments such as carotenoids and
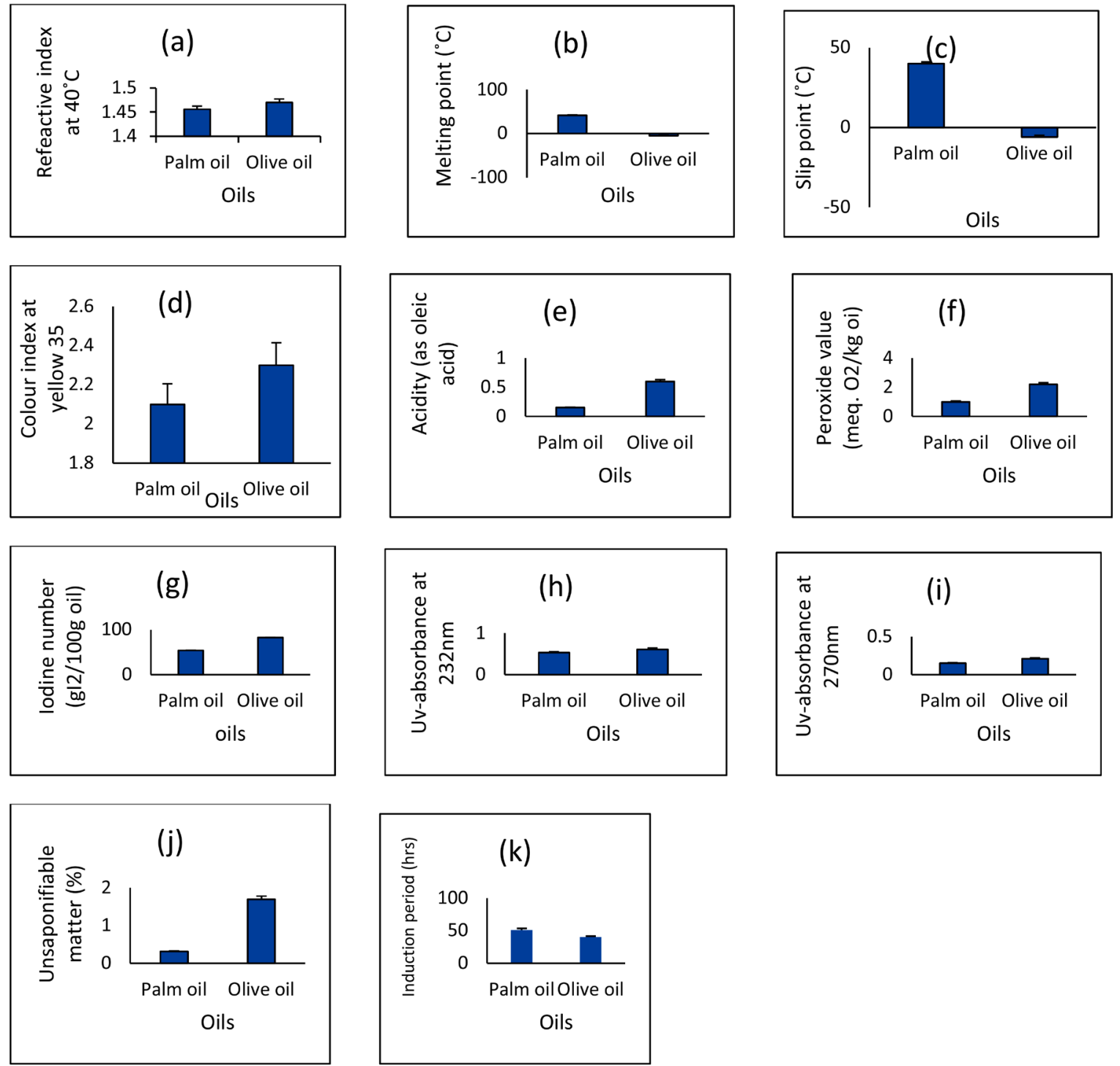

Figure 1. Physicochemical properties of the palm and olive oils used in producing cocoa butter Data are expressed as mean \pm SD values given represent means of three determinations. 
chlorophyll. According to data showed in Figure 1(e) the acidity of palm and olive oils amounted in 0.15 and 0.60 (mg KOH/g oil); respectively. Lower acid value content of palm oil may be due mainly to high content of saturated fatty acids specially the content of palmitic acid $\left(\mathrm{C}_{16: 0}\right)$ which makes the hydrolysis last more times [19]. Peroxide values (Figure 1(f)) of the tested vegetable oils was ranged from 1.00 to 2.20 (meq $\mathrm{O}_{2} / \mathrm{kg}$ oil) which found to be much greatly lower than that recommended values (within the permissible values) which should not exceed $15 \mathrm{meqO}_{2} / \mathrm{kg}$ oil as reported by [20].

The iodine value $\left(\mathrm{I}_{2} \mathrm{~g} / 100 \mathrm{~g}\right.$ oil $)$ is considered to be one of the most important chemical properties for quality assurance of lipids and as a good successful measure for changes occurs in the unsaturation degree of their content of fatty acid profiles. The data showed in Figure 1(g), illustrated that the iodine value of the investigated vegetable oils was ranged between 54.00 to $88.00 \mathrm{I}_{2} \mathrm{~g} / 100 \mathrm{~g}$ oil. The ultra-violet absorptions at 232 and $268 \mathrm{~nm}$ are taken as a good successful index for measuring the formation degree of conjugated fatty acids dienes and trienes [21]. Figure 1(h) \& Figure 1(i), demonstrated that the formation extent of conjugated fatty acids dienes of palm and olive oils were 0.50 and 0.60 , respectively. Meanwhile, the formations of conjugated fatty acid trienes for the same tested vegetable oils were 0.15 and 0.20 respectively The IP was measured by Rancimat method at $100^{\circ} \mathrm{C}$ for oils used in producing cocoa butter. Figure $1(\mathrm{j})$, the highest oxidative stability was to palm oil then olive oil (50.00 and 40.00 $\mathrm{hr}$ ). The significant differences in the induction period were mainly due to the different levels of total saturated fatty acids not only, but also the long or short carbon chain fatty acids and rather than total polyphenols and sterols for olive oil. Finally, Figure 1(k) it could be observed that olive oil contains the highest amount of unsaponifiable matter (\%) which recorded $1.70 \%$, meanwhile, the palm oil (0.31\%).

\subsection{Fatty Acids Composition (\%) of Palm and Olive Oils}

Fatty acid, including biochemical, physiological and functional functions, are essential components of the human body. They function as the key constituents of cell membranes as well as their position as a source of energy. In this case they maintain the fluidity, stability, permeability of the membrane as part of the membrane phospholipids, and therefore guarantee the passive movement across the membrane and are intertwined intra- and intercellularly with other proteins. The most significant fatty acid tends to be the dominant influence, the oxidative stress, neuroprotective effects and cardiovascular defense [22] as a consequence of their various biological functions. Table 1 shows the fatty acid composition of fatty acids of palm and olive oils, it could be observed that palmitic acid $\left(\mathrm{C}_{16: 0}\right)$ is found to be the major saturated fatty acid in palm oil (42.08\%). Meanwhile, higher content of oleic fatty acid $\left(\mathrm{C}_{18: 1}\right.$, omega-9) the major fatty acid it has many health effects such as lowering cholesterol, reducing the incidence of heart disease, was represented about $71.64 \%$ in olive oil. Also, the data showed in Table 1, that 
Table 1. Fatty acids composition (\%) of the palm and olive oils.

\begin{tabular}{ccc}
\hline Fatty acids & Palm oil & Olive oil \\
\hline $\mathrm{C}_{8: 0}$ & $0.29 \pm 0.02$ & $0.00 \pm 0.00$ \\
$\mathrm{C}_{10: 0}$ & $0.23 \pm 0.01$ & $0.00 \pm 0.00$ \\
$\mathrm{C}_{12: 0}$ & $0.21 \pm 0.01$ & $0.01 \pm 0.00$ \\
$\mathrm{C}_{1: 0}$ & $1.09 \pm 0.10$ & $0.11 \pm 0.01$ \\
$\mathrm{C}_{16: 0}$ & $42.08 \pm 3.01$ & $14.80 \pm 0.99$ \\
$\mathrm{C}_{16: 1}$ & $0.16 \pm 0.01$ & $0.07 \pm 0.01$ \\
$\mathrm{C}_{17: 0}$ & $0.10 \pm 0.01$ & $0.07 \pm 0.01$ \\
$\mathrm{C}_{18: 0}$ & $4.33 \pm 0.15$ & $1.78 \pm 0.07$ \\
$\mathrm{C}_{18: 1}$ & $40.25 \pm 2.91$ & $71.64 \pm 6.51$ \\
$\mathrm{C}_{18: 1 t}$ & $0.00 \pm 0.00$ & $0.00 \pm 0.00$ \\
$\mathrm{C}_{18: 2}$ & $10.95 \pm 0.98$ & $10.34 \pm 0.92$ \\
$\mathrm{C}_{18: 2 t}$ & $0.00 \pm 0.00$ & $0.00 \pm 0.00$ \\
$\mathrm{C}_{18: 3}$ & $0.19 \pm 0.02$ & $0.82 \pm 0.09$ \\
$\mathrm{C}_{20: 0}$ & $0.34 \pm 0.01$ & $0.12 \pm 0.02$ \\
$\mathrm{C}_{20: 1}$ & $0.16 \pm 0.01$ & $0.15 \pm 0.01$ \\
\hline
\end{tabular}

Data are expressed as mean \pm SD values given represent means of three determinations.

oils had no trans-fatty acids which are very harmful to human health [23].

\subsection{Physicochemical Properties of the Produced Cocoa Butter Substitute}

Cocoa butter substitutes are traditionally performed through hydrogenation. This process however, has always been regarded to produce trans-fatty acids that increase the health hazards [24]. The vegetable oils used in this research were palm and olive oils as well and were blended in different proportions according to the melting point to produce cocoa butter substitutes.

Figure 2(a), demonstrates that the refractive index at $40{ }^{\circ} \mathrm{C}$ for CBS-1, CBS-2 and CBS-3 was $1.4609,1.4632$ and 1.4665; respectively compared with CBS-C 1.4558 that showed clearly the narrow range degree of unsaturation. The melting and slip point of the produced cocoa butter substitutes are very important to be determined, as it will specify the aim, they could be produced for using in the confectionary industry with no harms to human body. Figure 2(a) \& Figure 2(b), the produced cocoa butter substitutes recorded the melting and slip point around the human body temperature $37^{\circ} \mathrm{C}$, compared with CBS-C (42.00 and $40.00^{\circ} \mathrm{C}$ ). That may due to the high saturated fatty acids it contained next to its fatty acid composition.

Figure 2(d), it could be clearly noticed that CBS-1, CBS-2 and CBS-3 had the same value of yellow scale as they were 35.00 . Also, the red color was scaled for CBS-1, CBS-2 and CBS-3, it was 2.22, 2.23 and 2.26, respectively, all these results 

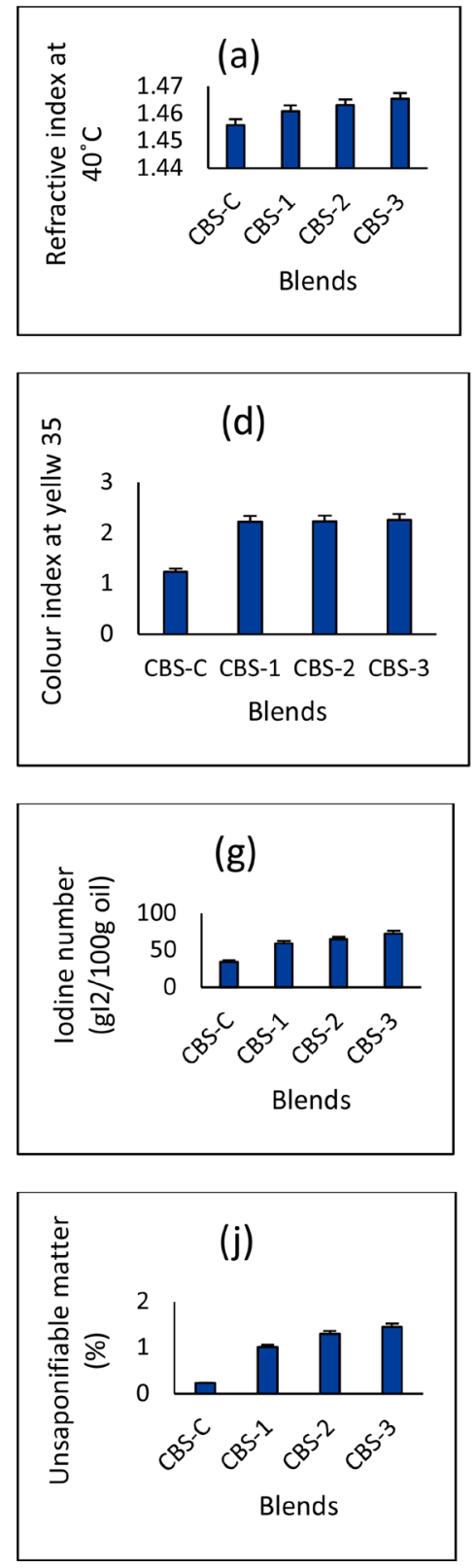
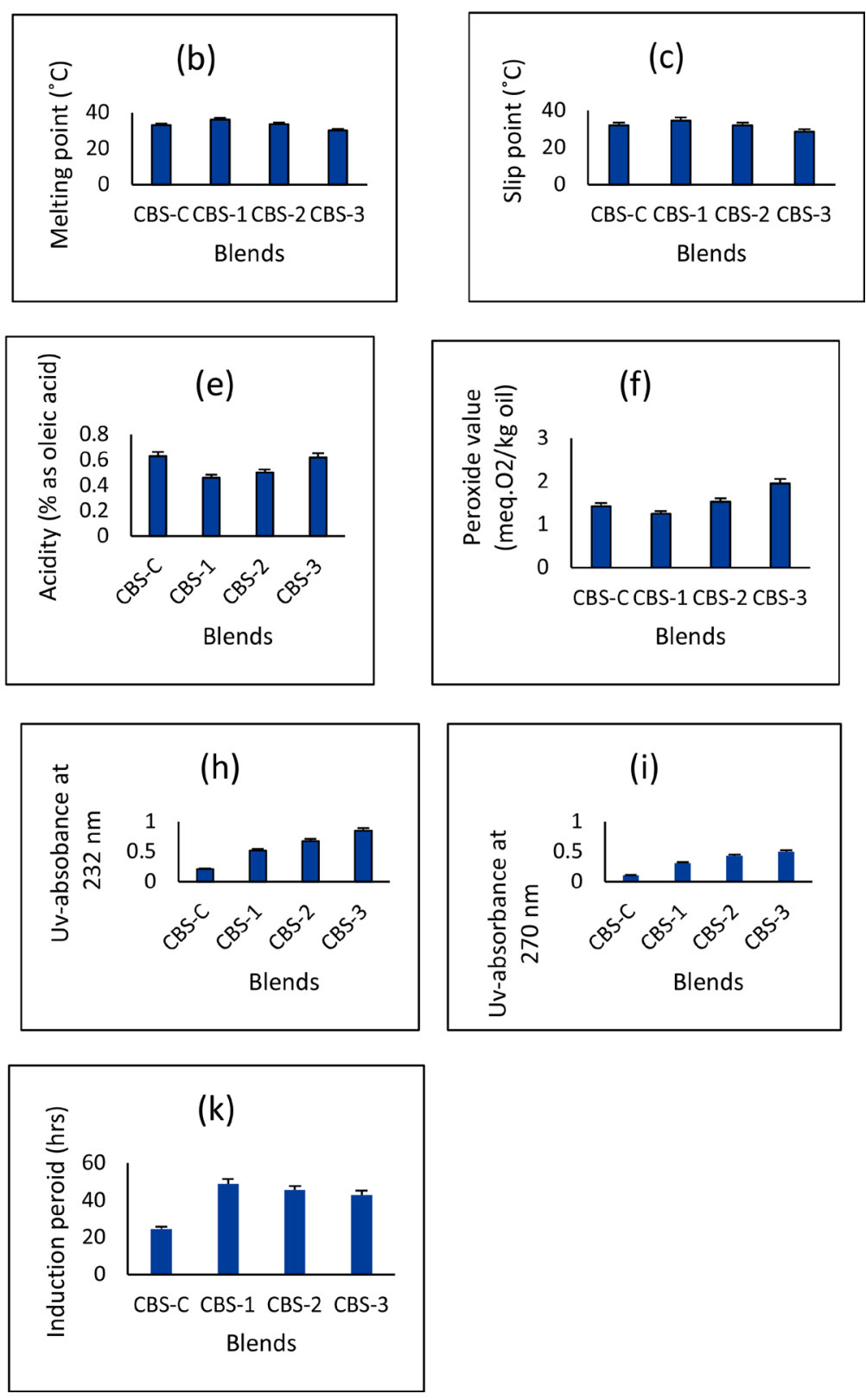

Figure 2. Physicochemical properties of the produced cocoa butter substitutes. Data are expressed as mean \pm SD values given represent means of three determinations.

were compared with CBS-C which scaled only 3.00 for yellow scale and 0.30 for red scale.

Results in Figure 2(e), indicated that the acidity (mg KOH/g oil) for CBS-1, CBS-2 and CBS-3, was $0.46,0.50$ and 0.62 , respectively compared with CBS-C which was $0.35 \mathrm{mg} \mathrm{KOH} / \mathrm{g}$ oil. Also, the peroxide value of the tested fats is found to be much greatly lower than that recommended value which should not exceed $15 \mathrm{meq} \mathrm{O}_{2} / \mathrm{kg}$ (Figure 2(f)). The present results are found to be much greatly lower within than that recommended (within the permissible values) for human consumption as reported by [20] for edible fats and oils. Figure 2(g), shows that the iodine value for all produced samples CBS-1, CBS-2 and CBS-3 was 59.50, 
64.90 and $72.40\left(\mathrm{I}_{2} / 100 \mathrm{~g}\right.$ oil), respectively, compared with CBS-C $7.50\left(\mathrm{I}_{2} / 100 \mathrm{~g}\right.$ oil) which showed the highest values of saturated fatty acids. The high iodine number of cocoa butter substitute produced due to blending with olive oil, which is characterized by its high content of oleic acid (omega-9).

With regards to the alteration in specific extinction at 232 and $268 \mathrm{~nm}$ as the measure of conjugated dienes and trienes fatty acids concentration in the tested samples as shown in Figure 2(h) \& Figure 2(i), It could be observed that the formation extent of conjugated fatty acid dines were $0.52,0.68$ and 0.85 , respectively for CBS-1, CBS-2 and CBS-3 compared with CBS-C (1.00). Meanwhile, the formations of conjugated fatty acid trienes were $0.31,0.43$ and 0.50 compared with CBS-C (0.30), respectively.

The induction period (IP), measuring the increase in the volatile components by-products released from the oxidizing fats and oils. The IP was measured by Rancimat method at $100^{\circ} \mathrm{C}$ for all the produced cocoa butter substitutes compared to the corresponding IP of the CBS-C which delivered from local market. The data showed in Figure 2(j), illustrated that higher induction period (hrs) for CBS-1, CBS-2 and CBS-3 where represented to be 52.00, 47.00 and $43.00 \mathrm{~h} / 100^{\circ} \mathrm{C}$, respectively, suggests their stronger oxidative stability when compared with CBS-C which recorded $35.00 \mathrm{~h} / 100^{\circ} \mathrm{C}$. The differences in the oxidative stability were mainly due to the different level of total saturated fatty acids not only, but also due to the long or short carbon chain fatty acids and rather than tocopherol content and other antioxidant compounds [25].

From the obtained data in Figure 2(k), it could be observed that the unsaponifiable matter \% of the produced cocoa butter substitutes CBS-1, CBS-2 and CBS-3 was $1.00 \%, 1.30 \%$ and $1.45 \%$; respectively, in compared with CBS-C which was $0.10 \%$.

\subsection{Fatty Acids Composition (\%) of the Produced Cocoa Butter Substitute}

From the data showed in Table 2, it could be concluded that all the produced cocoa butter substitute had a respective amount of lauric acid $\left(\mathrm{C}_{12: 0}\right)$ and the minor was belonged to CBS-1, CBC-2 and CBC-3 which was $0.25,0.06$ and $0.04 \%$ compared with CBS-C which recorded $40.78 \%$. Also, it could be observed that the cocoa butter substitute recorded the highest major saturated fatty acids palmitic acid $\left(\mathrm{C}_{16: 0}\right)$, which is represented $40.93 \%, 39.68 \%$ and $37.55 \%$, respectively. In contrast, CBS-C recorded the lowest amount $10.66 \%$. Besides, stearic acid $\left(\mathrm{C}_{18: 0}\right)$ was found in small amount for all the tested samples compared with CBS-C which recorded the highest respective amounted in $23.06 \%$. All the produced cocoa butter substitute contained the monounsaturated fatty acid (oleic acid $\left.\mathrm{C}_{18: 1}\right)$ in respective amount about $39.05 \%, 39.68 \%$ and $40.39 \%$ for CBS-1, CBS-2 and CBS-3, respectively. Also, data showed that all the produced cocoa butter substitute samples had no trans fatty acids which achieved the current investigation aim, when compared with $\mathrm{CBS}-\mathrm{C}$ that recorded $1.49 \%$ to $\left(\mathrm{C}_{18: 1}\right.$ trans). 
Table 2. Fatty acids composition (\%) of cocoa butter substitutes.

\begin{tabular}{ccccc}
\hline Fatty acids & CBS-C & CBS-1 & CBS-2 & CBS-3 \\
\hline $\mathrm{C}_{6: 0}$ & $0.24 \pm 0.01$ & $0.00 \pm 0.00$ & $0.00 \pm 0.00$ & $0.00 \pm 0.00$ \\
$\mathrm{C}_{8: 0}$ & $3.85 \pm 0.12$ & $0.32 \pm 0.02$ & $0.52 \pm 0.04$ & $0.18 \pm 0.01$ \\
$\mathrm{C}_{10: 0}$ & $4.23 \pm 0.23$ & $0.28 \pm 0.01$ & $0.55 \pm 0.05$ & $0.57 \pm 0.07$ \\
$\mathrm{C}_{12: 0}$ & $40.78 \pm 2.41$ & $0.25 \pm 0.01$ & $0.06 \pm 0.01$ & $0.04 \pm 0.01$ \\
$\mathrm{C}_{1: 0}$ & $14.14 \pm 0.73$ & $4.71 \pm 0.27$ & $4.41 \pm 0.13$ & $3.48 \pm 0.12$ \\
$\mathrm{C}_{16: 0}$ & $10.66 \pm 0.50$ & $40.93 \pm 2.87$ & $39.68 \pm 2.00$ & $37.55 \pm 2.01$ \\
$\mathrm{C}_{16: 1}$ & $0.33 \pm 0.10$ & $0.17 \pm 0.01$ & $0.11 \pm 0.01$ & $0.12 \pm 0.01$ \\
$\mathrm{C}_{17: 0}$ & $0.02 \pm 0.00$ & $0.06 \pm 0.01$ & $0.09 \pm 0.01$ & $0.08 \pm 0.01$ \\
$\mathrm{C}_{18: 0}$ & $23.06 \pm 1.00$ & $4.11 \pm 0.15$ & $3.7 \pm 0.12$ & $3.00 \pm 0.10$ \\
$\mathrm{C}_{18: 1}$ & $0.77 \pm 0.09$ & $39.05 \pm 1.98$ & $39.66 \pm 1.90$ & $43.20 \pm 2.03$ \\
$\mathrm{C}_{18: 1 t}$ & $1.49 \pm 0.10$ & $0.00 \pm 0.00$ & $0.00 \pm 0.00$ & $0.00 \pm 0.00$ \\
$\mathrm{C}_{18: 2}$ & $0.01 \pm 0.00$ & $9.66 \pm 0.51$ & $9.70 \pm 0.45$ & $10.84 \pm 0.91$ \\
$\mathrm{C}_{18: 2 \mathrm{t}}$ & $0.10 \pm 0.00$ & $0.07 \pm 0.01$ & $0.02 \pm 0.01$ & $0.01 \pm 0.00$ \\
$\mathrm{C}_{18: 3}$ & $0.07 \pm 0.00$ & $0.28 \pm 0.01$ & $0.81 \pm 0.08$ & $0.91 \pm 0.06$ \\
$\mathrm{C}_{20: 0}$ & $0.22 \pm 0.01$ & $0.68 \pm 0.03$ & $0.28 \pm 0.01$ & $0.30 \pm 0.02$ \\
$\mathrm{C}_{20: 1}$ & $0.00 \pm 0.00$ & $0.14 \pm 0.01$ & $0.13 \pm 0.01$ & $0.11 \pm 0.01$ \\
\hline
\end{tabular}

Data are expressed as mean \pm SD values given represent means of three determinations.

The process of blending olive oil with palm oil to produce cocoa butter led to an increase in the proportion of monounsaturated fatty acids. Therefore, the produced cocoa butter substitute in this research is healthy because oleic acid (omega-9) works to lower cholesterol, reduce heart diseases and atherosclerosis.

\subsection{Solid Fat Content}

The amount of fat crystals in a fat or fat combination has a significant influence on the suitability of a fat or fat combination for a specific application [26]. A significant number of product features, including their general appearance, are responsible for solid fat, margarines, cutbacks and fat diffusion, spread ability, and for sure for cocoa butter alternatives in confectionary industry, oil oxidation and organoleptic properties [6].

Solid fat content $(\%)$ versus temperature $\left(10^{\circ} \mathrm{C}-50^{\circ} \mathrm{C}\right)$ for the produces cocoa butter substitute is given in Figure 3, solid fat content versus temperature plot generally gives not only the information on how hard or soft a fat is at different temperatures but also the melting behavior of the fat. it was observed that solid fat content decreased with increased olive oil proportion in the blend. These variations in the solid fat content are mainly due to differences in the fatty acid contents of oils.

\subsection{Total Polyphenols}

Polyphenols are a key component to extra virgin olive oil, and are considered to be one of the best health benefits within the oil. Polyphenols furnish the immune 
system, protect us from heart diseases and display anticancer activity as they act as free radicals traps. They protect olive oil from oxidative damage and they contribute to its superior oxidative stability among other edible oils. They also affect its taste, giving it a distinctive bitter flavor [27], Figure 4 shows the total polyphenols of palm and olive oils and produced cocoa butter substitute. The results indicate a higher content of phenolic compounds in olive oil (490.00 ppm) than palm oil (40.00 ppm). All samples of cocoa butter substitute (CBS-1, CBS-2 and CBS-3) producing by blending olive oil with palm oil were higher in their content of phenolic compounds (95.70, 140.50 and $190.00 \mathrm{ppm}$ ) compared to CBS-C (10.00 ppm). The presence of phenolic compounds in the produced cocoa butter substitute makes it of high health and nutritional value and leads to

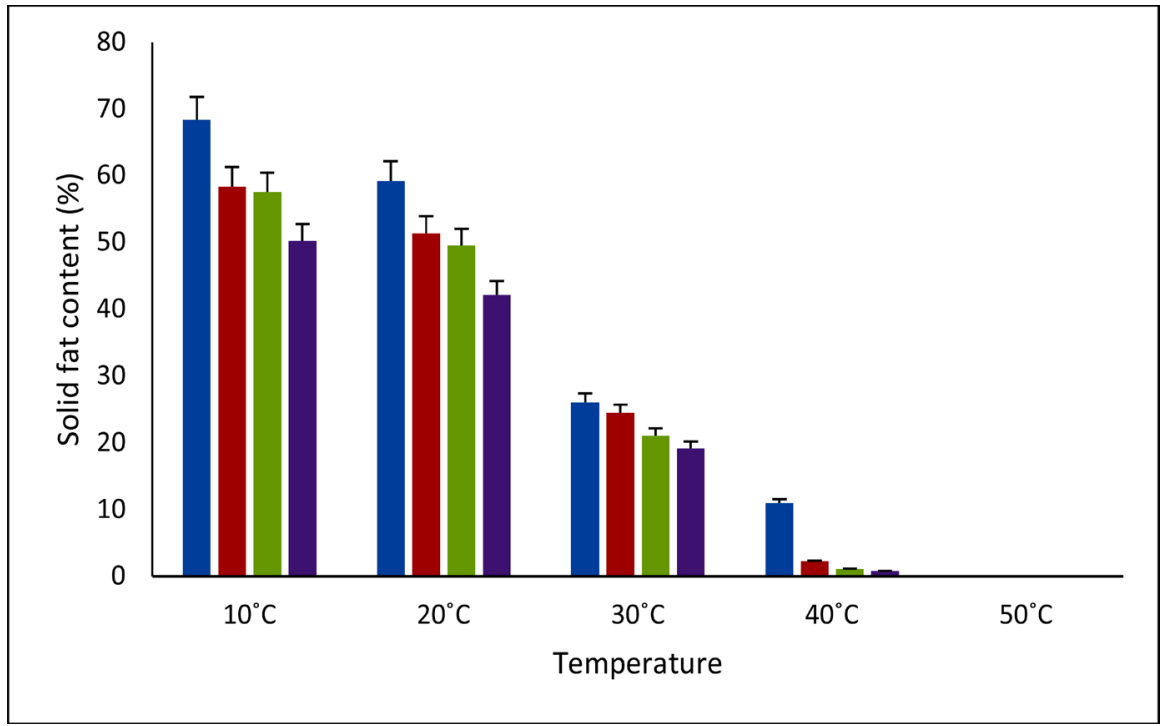

Figure 3. Solid fat content of cocoa butter substitutes. Data are expressed as mean \pm SD values given represent means of three determinations.

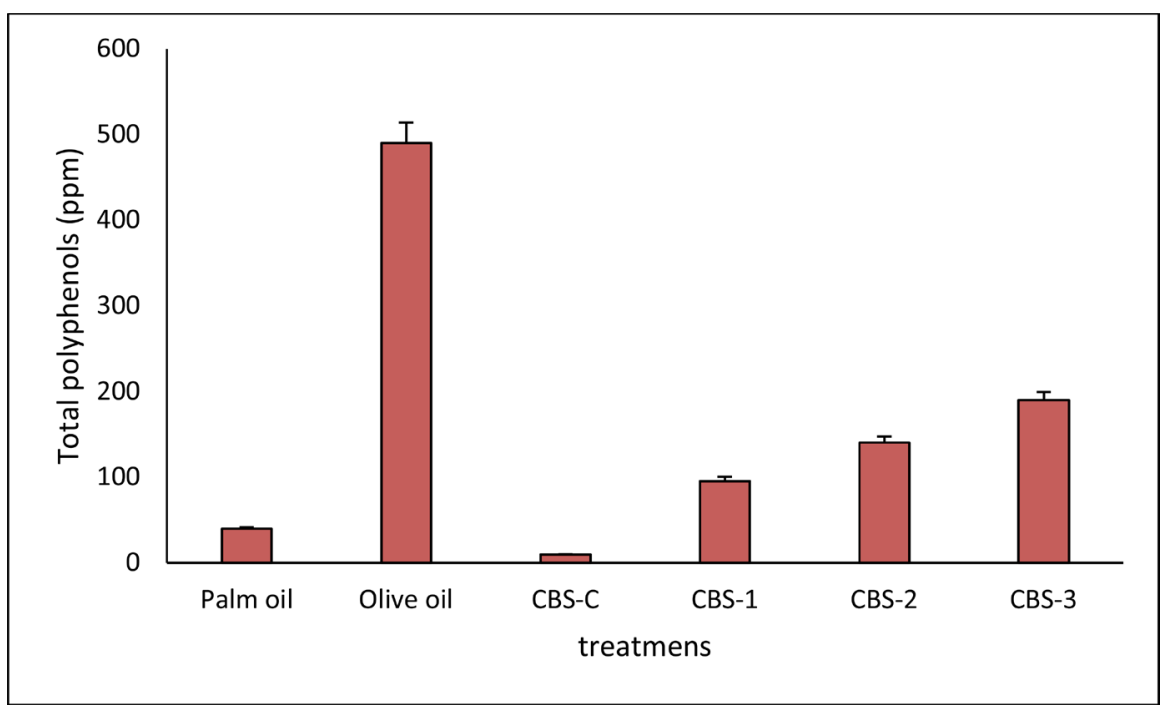

Figure 4. Total polyphenols of oils and cocoa butter substitute. Data are expressed as mean \pm SD values given represent means of three determinations. 
an increase in its shelf life.

\section{Conclusion}

The results recommend using extra virgin olive oil in producing healthy cocoa butter substitute because it is characterized by a unique composition of monounsaturated fatty acids (oleic acid, omega-9) that reduce heart disease and arteriosclerosis, as well as phenolic compounds that act as natural antioxidants which contribute to the prevention of many diseases.

\section{Conflicts of Interest}

The authors declare no conflicts of interest regarding the publication of this paper.

\section{References}

[1] Joanna, O., Ewa, N. and Dorota, Z. (2014) Effect of Roasting Conditions on the Fat, Tocopherol, and Phytosterol Content and Antioxidant Capacity of the Lipid Fraction from Cocoa Beans of Different Theobroma cacao L. Cultivars. European Journal of Lipid Science and Technology, 116, 1002-1014.

https://doi.org/10.1002/ejlt.201300474

[2] Biswas, N., Cheow, Y.L., Tan, C.P. and Siow, L.F. (2016) Blending of Palm Mid-Fraction, Refined Bleached Deodorized Palm Kernel Oil or Palm Stearin for Cocoa Butter Alternative. Journal of the American Oil Chemists' Society, 93, 1415-1427. https://doi.org/10.1007/s11746-016-2880-z

[3] Wei, Y., Bergenholm, D., Gossing, M., Siewers, V. and Nielsen, J. (2018) Expression of Cocoa Genes in Saccharomyces cerevisiae Improves Cocoa Butter Production. Microbial Cell Factories, 17, Article No. 11. https://doi.org/10.1186/s12934-018-0866-2

[4] Voora, V., Bermúdez, S. and Larrea, C. (2019) Global Market Report: Cocoa. International Institute for Sustainable Development, Winnipeg.

[5] Läderach, P., Martinez-Valle, A., Schroth, G. and Castro, N. (2013) Predicting the Future Climatic Suitability for Cocoa Farming of the World's Leading Producer Countries, Ghana and Côte d'Ivoire. Climatic Change, 119, 841-854. https://doi.org/10.1007/s10584-013-0774-8

[6] Rios, R.V., Pessanha, M.D.F., de Almeida, P.F., Viana, C.L. and da Silva Lannes, S.C. (2014) Application of Fats in Some Food Products. Food Science and Technology, 34, 3-15. https://doi.org/10.1590/S0101-20612014000100001

[7] Undurraga, D., Markovits, A. and Erazo, S. (2001) Cocoa Butter Equivalent through Enzymic Interesterification of Palm Oil Midfraction. Process Biochemistry, 36, 933-939. https://doi.org/10.1016/S0032-9592(00)00260-0

[8] Quek, C.R., Peh, E.W. and Henry, C.J. (2020) Effects of Cocoa Butter and Cocoa Butter Equivalent in a Chocolate Confectionery on Human Blood Triglycerides, Glucose and Insulin. Foods, 9, 455-456. https://doi.org/10.3390/foods9040455

[9] Çiftçi, O.N., Fadıloğlu, S. and Göğüş, F. (2009) Conversion of Olive Pomace Oil to Cocoa Butter-Like Fat in a Packed Bed Enzyme Reactor. Bioresource Technology, 100, 324-329. https://doi.org/10.1016/j.biortech.2008.05.035

[10] Esposto, S., Selvaggini, R., Taticchi, A., Veneziani, G., Sordini, B. and Servili, M. (2020) Quality Evolution of Extra-Virgin Olive Oils According to Their Chemical Composition during 22 Months of Storage under Dark Conditions. Food Chemi- 
stry, 311, 126044. https://doi.org/10.1016/j.foodchem.2019.126044

[11] International Olive Council (IOC) (2019) Trade Standard Applying to Olive Oils and Olive-Pomace Oils. COI/T.15/Nc No 3/Rev. 14 2019, Madrid.

[12] Pavithra, N.R., Prakash, M. and Kodangala, K.B. (2006) Quality Assessment of Oil Blends by Electronic Nose Technique and Sensory Methods. Journal of Sensory Studies, 21, 322-332. https://doi.org/10.1111/j.1745-459X.2006.00068.x

[13] Kiritsakis, A.P.K., Lenart, E.B., Willet, W.C. and Hernandez, R.J. (1998) Olive Oil from the Tree to the Table. Food and Nutrition Press, Trumbull.

[14] Smith, K.W. (2001) Cocoa Butter and Cocoa Butter Equivalents. In: Gunstone, F., Ed., Structured and Modified Lipids, Unilever Research Colworth, Bedfordshire, 401-422.

[15] A.O.C.S. (2012) Official and Tentative Methods of the American Chemists Society. 17th Edition, American oil Chemists Society 508, Champaign, 6182.

[16] Berrin, B. and Feral, T. (2008) Chemical Composition and Oxidative Stability of Flax, Safflower and Poppy Seed and Seed Oils. Bioresource Technology, 99, 6354-6359. https://doi.org/10.1016/j.biortech.2007.12.009

[17] A.O.C.S. (2017) Official Methods and Recommended Practices of the American Oil Chemists Society. 7th Edition, 2nd Printing, A.O.C.S., Champaign, AOAC International, 18th Edition.

[18] Gutfinger, T. (1981) Polyphenols in Olive Oils. Journal of the American Oil Chemists' Society, 58, 966-968. https://doi.org/10.1007/BF02659771

[19] Onwuliri, V.A., Igwe, C.U. Golu, M.D. and Agha, N.C. (2011) Assessment of the Quality of Some Edible Vegetable Oils Consumed in Northern Nigeria Australian Journal of Basic and Applied Sciences, 5, 897-905.

[20] Egyptian Standard Specifications (2005) Vegetable Edible Oils, Edible Palm Oil (1520/2005, ICS. 67.200). Egyptian Organization for Standardization and Quality Control, Ministry of Industry and Technological Development, ARE.

[21] Endo, Y. (2018) Analytical Methods to Evaluate the Quality of Edible Fats and Oils: The JOCS Standard Methods for Analysis of Fats, Oils and Related Materials (2013) and Advanced Methods. Journal of Oleo Science, 67, 1-10. https://doi.org/10.5650/jos.ess17130

[22] Nagy, K. and Tiuca, L. (2017) Importance of Fatty Acids in Physiopathology of Human Body. Fatty Acids, Angel Catala, Intech Open.

https://doi.org/10.5772/67407

[23] FAO (2010) Food and Agriculture Organization, Food and Nutrition Paper 91. Fats and Fatty Acids in Human Nutrition, Report of an Expert Consultation.

[24] Wang, F., Liu, Y., Jin, Q., Meng, Z. and Wang, X. (2011) Characterization of Cocoa Butter Substitutes, Milk Fat and Cocoa Butter Mixtures. European Journal of Lipid Science and Technology, 113, 1145-1151. https://doi.org/10.1002/ejlt.201000488

[25] Imogen, F. (2003) Model Building of the Isotherm Cocoa Butter Crystallization Influence of Temperature and Chemical Composition. Ph.D. Thesis, Ghent University, Ghent.

[26] Lipp, M. and Anklam, E. (1998) Review of Cocoa Butter and Alternative Fats for Use in Chocolate-Part A. Compositional Data. Food Chemistry, 62, 73-97. https://doi.org/10.1016/S0308-8146(97)00160-X

[27] Kouka, P., Tsakiri, G., Tzortzi, D., Demopoulo, S., Sarikaki, G., Stathopoulos, P., Aristidis, S., Halabalaki, M., Skaltsounis, A.-L. and Kouretas, D. (2019) The Polyphenolic Composition of Extracts Derived from Different Greek Extra Virgin Olive Oils Is Correlated with Their Antioxidant Potency. Oxidative Medicine and Cellular Longevity, 2019, Article ID: 1870965. https://doi.org/10.1155/2019/1870965 